\title{
Study of feces of neotropical otters (Lontra longicaudis) in the Ayuquila-Armería basin, Mexico as biomonitors of the spatiotemporal distribution of pesticides
}

\section{Luis Manuel Martinez Rivera ( $\nabla$ Imartinez@cucsur.udg.mx )}

Universidad de Guadalajara Centro Universitario de la Costa Sur https://orcid.org/0000-0002-70509385

Brian Rodríguez-Aguilar

Universidad de Guadalajara Centro Universitario de la Costa Sur Luis Martínez-Rivera

Universidad de Guadalajara Centro Universitario de la Costa Sur

\section{Roberto Muñiz-Valencia}

Universidad Bernardo O'Higgins

\section{Norman Mercado-Silva}

Universidad Autonoma del Estado de Morelos

Luis ignacio Iñiguez-Dávalos

Universidad de Guadalajara Centro Universitario de la Costa Sur

Alejandro Aaron Peregrina-Lucano

Universidad de Guadalajara Centro Universitario de Ciencias Exactas e Ingenieria

\section{Research Article}

Keywords: pesticides, biomonitors, neotropical otter, non-invasive sampling, feces

Posted Date: August 18th, 2021

DOl: https://doi.org/10.21203/rs.3.rs-817307/v1

License: (c) (i) This work is licensed under a Creative Commons Attribution 4.0 International License. Read Full License 


\section{Abstract}

The pesticides used have contributed to increasing food production, it has also caused them to be found in most ecosystems and have negative effects on biota. The neotropical otter (Lontra longicaudis) is vulnerable to pesticides accumulation and is characterized by being elusive, so it is necessary to address the use of indirect techniques that evaluate its populations' state in an efficient, logistically simple, and non-invasive way. This study aimed to determine the concentration of 20 pesticides in neotropical otter feces in the Ayuquila-Armería basin and to describe the spatiotemporal variation of these pesticides. The presence of 11 pesticides was determined. Imazalil, picloram, and malathion the pesticides with the highest concentrations; emamectin, $\lambda$-cyhalothrin, methomyl, and picloram were present in all samples. Emamectin was the only pesticide that presented significant differences concerning the temporality of the samplings, presenting higher concentrations in the wet season. Molinate concentrations showed significant differences concerning the location of the sampling sections in the basin, the lower part of the basin presented higher concentrations. The distribution of the populations of $L$. longicaudis in the Ayuquila-Armería basin does not respond to the degree of contamination by pesticides in surface waters or to the proximity to agricultural activities, and this in places with evident chemical and organic contamination and human presence. The use of otter feces for pesticide monitoring is an accepted noninvasive method to assess the degree of exposure and can be used to determine sites with pollution problems.

\section{Introduction}

The so-called "Green Revolution" was an international campaign in developing countries to modernize agriculture through the use of high amounts of synthetic fertilizers and pesticides (Albert 2005; BejaranoGonzález 2017). This agricultural model generated a great increase in global production; however, the intensive use of synthetic pesticides has led to negative effects on biota and humans (Pinto et al. 2016; Sumon et al. 2018). Agriculture in Mexico is increasingly dependent on the use of agrochemicals to obtain greater productivity and profitability, without considering the adverse effects that they produced on biota and human health (Benítez-Díaz and Miranda-Contreras 2013). Many pesticides currently used in agriculture have toxic characteristics representing a risk to living beings, e. g. some present high environmental persistence and hydrophobicity which result in biomagnification processes within the food chain (Shukla et al. 2006; Arias-Estévez et al. 2008). In this sense, the presence of pesticide residues in an aquatic organism not only affects the species that accumulate it but also means an important source of contamination for their predators (LeDoux 2011).

The neotropical otter (Lontra longicaudis) is a semiaquatic mammal that has a wide distribution that ranges from northern Mexico and the southern U.S.A to central Argentina. Its habitat includes rivers, lakes, streams, dams, and coastal lagoons, as well as dams and artificial channels. It is found both in tropical forests and subtropical forests, in a variety of climatic conditions (Gallo-Reynoso 1997; Larivière 1999; Gallo-Reynoso and Casariego 2005). The neotropical otter is considered the top predator species of its food network, therefore maintain the ecological balance of its habitat (Ramos-Rosas et al. 2012). It feeds 
on a wide variety of species, mainly fish, crustaceans, mollusks, and insects, and to a lesser extent, reptiles, birds, and small mammals (Gallo-Reynoso et al. 2008; Monroy-Vilchis and Mundo 2009; RangelAguilar and Gallo-Reynoso 2013). The neotropical otter is classified as a near-threatened species by the International Union for Conservation of Nature (IUCN), also it is included in Appendix I of the Convention on International Trade in Endangered Species of Wild Flora and Fauna (CITES); in Mexico, it is classified as a threatened species by NOM-059-SEMARNAT-2010 (SEMARNAT 2010; Rheingantz and Trinca 2015; CITES 2019).

Otters are considered good biomonitors of aquatic ecosystems pollution by pesticides, due to the pesticide biomagnification process through their diet and by their continuous exposition to potentially polluted water. Also, pesticide concentration in otters can reveal temporal and spatial changes in contamination of an ecosystem (Zhou et al. 2008; Ramos-Rosas et al. 2012). Furthermore, studies on otters can contribute to the evaluation of potential risks on human health, due to the coincidences in the diet along with the continuous exposure to different contaminated matrices (Lemarchand et al. 2007; Ramos-Rosas et al. 2012; Carpenter et al. 2014).

Because the neotropical otter is an elusive species, its direct study in nature becomes a difficult task, so the use of indirect sampling or techniques is considered an efficient option for monitoring (Gutleb and Kranz 1997; Elliott et al. 2008). Otter feces have been used as an indirect technique to assess both feeding habitats, and their level of pollution, in an efficient, logistically simple, and non-invasive way (Gutleb and Kranz 1997; Lemarchand et al. 2007; Elliott et al. 2008). From those studies, it can be concluded that organochlorine pesticide concentrations in otters can harm their reproductive success and their survival (Mason and Macdonald 1993; Kruuk et al. 1997; Roos et al. 2012; Carpenter et al. 2014). Most studies have focused mainly on the determination of highly toxic organochlorine pesticides. However, they do not represent the current situation since organophosphates, carbamates, and pyrethroids are currently the most used worldwide pesticides and are poorly reported in the literature (Lemarchand et al. 2011). The variations of pesticide concentrations in the neotropical otter's feces generate a panorama of the contamination level present in the food chain of the ecosystem, the exposure degree of wildlife to pollutants, and the recent intake of pesticides because of contaminated species consumption. This consecutively contributes to the identification of areas with greater contamination problems (Mason and Ratford 1994; Delibes et al. 2009; Ramos-Rosas et al. 2012).

The Ayuquila-Armería basin is located between the states of Jalisco and Colima, Mexico. This basin is one of the most important in western Mexico. The main economic activities carried out within this basin are intensive and subsistence agriculture, and timber production; there is also cattle raising and fishing but to a lesser extent (Santana et al. 1993; Meza-Rodríguez 2006; Mercado-Silva et al. 2011). The monoculture of sugarcane is one of the most economically important productive activities in the basin. However, it has intensive production practices that are highly dependent on the use of pesticides resulting in adverse effects on biota. In the Ayuquila-Armería basin zone, at least 143 pesticide active ingredients 
are marketed, and the most commonly used pesticides are glyphosate, carbofuran, malathion, ametrine, paraquat, cypermethrin, and atrazine (Rodríguez-Aguilar et al. 2019).

Despite the ecological importance of the neotropical otter within the Ayuquila-Armería basin, it is continuously affected due to the productive activities, such as deforestation of riparian vegetation, channeling of tributary rivers, dredging activities, livestock, urban and industrial residual discharges, and alteration of the hydrological regime causing habitat modification as well as capture or hunting by fishermen (Santana et al. 1993; Lyons et al. 1998; Meza-Rodríguez 2006; Mercado-Silva et al. 2011). The combination of these factors in the Ayuquila-Armería basin increases the negative impacts on the aquatic ecosystem and to generating deleterious effects on the neotropical otter population. The aims of this study were 1) to determine the concentration in neotropical otter's feces of twenty pesticides in current use the Ayuquila-Armería basin, and 2) to describe the temporal and spatial variation of those pesticides.

\section{Materials And Methods}

\subsection{Sampling area}

A total of 10 sections of the basin were chosen as sampling areas based on the main sources of contamination by domestic, industrial, and agricultural residual discharges, such as the Melchor Ocampo sugarcane mill, the agave crop and greenhouse area of the municipality of San Gabriel, Jalisco, and the domestic residual discharges of Autlán de Navarro and El Grullo cities (Figure 1). Each section had an extension of $5 \mathrm{~km}$ along with the streamflow, and the separation between each of the sections was at least $5 \mathrm{~km}$; we considered that each sampling section had an independent subpopulation, based on the home range of the otters (Gallo-Reynoso 1989).

The sampling sections present different land uses associated with different productive activities, such as irrigation and temporary agriculture, urban settlements, and canyon area. The sampling sections (S) are found within different geoforms, sections where the slope is steep (canyons) and others where it is not (valleys), which is an important aspect that can determine the productive activities surrounding each study section (Table 1). The sampling sections S2, S3, S6, S9, and S10 are located in areas with irrigated or seasonal agriculture and urban settlements. The other sections (S1, S4, S5, S7, and S8) are located mainly in canyon areas with vegetation predominantly of deciduous tropical dry forest. The Trigomil dam is located approximately $11 \mathrm{~km}$ north of sampling section 1 . This dam is the largest in the AyuquilaArmería basin, with a maximum volume of $250 \mathrm{Mm}^{3}$, and fragments the longitudinal continuity of the river (Meza-Rodríguez 2006).

Table 1. Morphology physical and land use of the surface water sampling sections in the AyuquilaArmería river basin. 


\begin{tabular}{|c|c|c|c|c|c|}
\hline $\begin{array}{l}\text { Sampling } \\
\text { sections }\end{array}$ & Sub-basin & $\begin{array}{l}\text { Location in } \\
\text { basin }\end{array}$ & $\begin{array}{l}\text { Geoform } \\
\text { type }\end{array}$ & $\begin{array}{l}\text { Stream order } \\
\text { (Strahler) }\end{array}$ & Land use \\
\hline $\begin{array}{l}\text { Corcovado } \\
\text { (S1) }\end{array}$ & Ayuquila & Middle & Canyon & 7 & DTDF \\
\hline $\begin{array}{l}\text { El Chacalito } \\
\text { (S2) }\end{array}$ & Ayuquila & Middle & Valley & 7 & Sugarcane \\
\hline $\begin{array}{l}\text { El Aguacate } \\
\text { (S3) }\end{array}$ & Ayuquila & Middle & Valley & 7 & Sugarcane \\
\hline Ventanas (S4) & Ayuquila & Middle & Canyon & 7 & DTDF \\
\hline $\begin{array}{l}\text { Zenzontla } \\
\text { (S5) }\end{array}$ & Ayuquila & Middle & Canyon & 7 & DTDF \\
\hline $\begin{array}{l}\text { San Miguel } \\
\text { (S6) }\end{array}$ & Tuxcacuesco & Middle & Valley & 8 & Sugarcane \\
\hline La Croix (S7) & Tuxcacuesco & Middle & Canyon & 6 & $\begin{array}{l}\text { Agave and } \\
\text { greenhouses }\end{array}$ \\
\hline $\begin{array}{l}\text { Zacualpan } \\
\text { (S8) }\end{array}$ & Armería & Lower & Canyon & 7 & DTDF \\
\hline El Chical (S9) & Armería & Lower & Valley & 7 & Sugarcane \\
\hline Armería (S10) & Armería & Lower & Valley & 8 & Sugarcane \\
\hline
\end{tabular}

DTDF = Deciduous tropical dry forest.

The pesticides under study were selected because they are commonly used in agricultural activities and marketed within the Ayuquila-Armería basin (Rodríguez-Aguilar et al. 2019). The selected pesticides were 2,4-D, acetochlor, ametrine, atrazine, carbendazim, carbofuran, diazinon, dimethoate, emamectin, glyphosate, imazalil, $\lambda$-cyhalothrin, malathion, methomyl, metoxuron, molinate, parathion, picloram, pyraclostrobin, and thiabendazole. These pesticides are used to control different types of organisms and they are representative of different chemical classes such as fungicides, insecticides, and herbicides. Due to the different productive activities and crop heterogeneity in the basin, the evaluation of the temporal and spatial distribution of pesticides should be accomplished considering pesticides with different physicochemical characteristics.

\subsection{Sampling collection}

In each study section, four samplings over two years were carried out. Two samplings during the dry season (February 2018 and 2019) and two during the wet season (November 2018 and 2019). The neotropical otter's feces were identified based on a methodology published by Aranda-Sánchez (2012). The sampling sections were covered entirely on foot, looking for feces in the rocks and logs inside the streamflow, as well as in areas surrounding it (10 $\mathrm{m}$ on each side of the river). The samples were identified and taken following the procedure described by Elliot et al. (2008), collecting them manually 
with latex gloves. To avoid feces samples contamination during the fieldwork, immediately after collection, they were placed in polyethylene bags with hermetic closures.

During transport and fieldwork, the samples were placed in an icebox, keeping them at $4{ }^{\circ} \mathrm{C}$ to increase preservation time and decrease microbial activity. At the laboratory, the samples were dried in an oven at $40{ }^{\circ} \mathrm{C}$ for $5 \mathrm{~h}$ and subsequently screened in sieves cascaded to a $2 \mathrm{~mm}$ opening, separating the bone material, fish scales, and exoskeletons, to obtain the finest material and facilitate the pretreatment process and extraction of pesticides from samples. Finally, the sieved material was stored in dark at -20 ${ }^{\circ} \mathrm{C}$ until treatment.

Composite samples of each sampling section were prepared by combining collected feces on the same date and sampling section. Thus, four composite samples from each sampling section were obtained. So, the sampling sections were treated as the primary sampling units. The volume of the composite samples varied according to the number of feces collected in each sampling section.

\subsection{Sample pretreatment, solid-phase extraction, and pesticides determination.}

Pretreatment of feces of neotropical otter samples consisted of leaching of pesticides from samples into an aqueous phase. To leach the analytes in an aqueous phase, $1 \mathrm{~g}$ of each composite sample was placed in a $15 \mathrm{ml}$ centrifuge tube. Subsequently, a mixture of acetonitrile and ultrapure water (1:9, vol: vol) was added to the centrifuge tube and placed in an ultrasound bath for $15 \mathrm{~min}$, all solvents were of analytical grade and obtained from Sigma-Aldrich ${ }^{\circledR}$. After that time, the tube was immediately centrifuged for $15 \mathrm{~min}$ at $25^{\circ} \mathrm{C}$ and $3500 \mathrm{rpm}$, in a LaboGene ${ }^{\circledR}$ model $1580 \mathrm{R}$ centrifuge. Finally, $5 \mathrm{~mL}$ of aqueous phase supernatant was diluted to $50 \mathrm{~mL}$ with ultrapure water for SPE extraction.

Sample clean-up and analytes concentration/extraction were carried out using Supel-select HLB 500 $\mathrm{mg} / 12 \mathrm{~mL}$ solid-phase extraction (SPE) cartridges obtained from Supelco. Before pesticide extraction, the cartridges were conditioned passing $5 \mathrm{~mL}$ of $\mathrm{MeOH}$ and $10 \mathrm{~mL}$ of ultrapure water through them. The 50 $\mathrm{mL}$ leachate of the sample was passed through the cartridge at a $2 \mathrm{~mL} \mathrm{~min}^{-1}$ flow rate. After that, the cartridge was washed with $10 \mathrm{~mL}$ of ultrapure water and vacuum drying for 5 minutes. The elution of the analytes was carried out using $5 \mathrm{~mL}$ of $\mathrm{MeOH}$. Finally, the sample was evaporated to $1 \mathrm{~mL}$ at $30^{\circ} \mathrm{C}$ under a gentle $\mathrm{N}_{2}$ flow. The final extract was placed in a $2 \mathrm{~mL}$ vial for pesticide determination using liquid chromatography equipment coupled to a tandem mass spectrometry detector.

Quantification of the 20 pesticides in feces of neotropical otter samples was carried out utilizing a column Zorbax Eclipse XDB-C18 Rapid Resolution $2.1 \mathrm{~mm}$ internal diameter x $50 \mathrm{~mm}$ long, $3.5 \mathrm{~mm}$ particle size connected to a liquid chromatograph model 1200 coupled to tandem mass spectrometer detector model 6430B, all from Agilent Technologies. The software used for data acquisition was MassHunter Workstation Acquisition and MassHunter Workstation Quantitative Analysis. For this purpose, two analytical methods were used, one for 2,4-D and glyphosate, and the other for acetochlor, ametrine, atrazine, carbendazim, carbofuran, diazinon, dimethoate, emamectin, imazalil, $\lambda$-cyhalothrin, malathion, methomyl, metoxuron, molinate, parathion, picloram, pyraclostrobin, and thiabendazole. The 
separation and detection conditions of the two analytical methods used are described in Sierra-Díaz et al. (2019).

\subsection{Statistical analysis}

Statistical analysis was performed using a Kruskal-Wallis test to assess whether the number of pesticides detected per sample differs by season. Also, an ANOVA test to define whether the number of pesticides detected per sample differs by sampling was addressed. The assumption for normality was determined using the Shapiro-Wilk test.

Statistical analysis was performed to estimate significant differences in the concentrations of each pesticide by season and sampling. For pesticides with detection frequency between $20 \%$ and $99 \%$ in the total samples, a statistical analysis through left-censored data with non-parametric Kaplan-Meier test and parametric with Maximum likelihood estimation was carried out, using the software R project version 3.6.2, with survival version 3.1-8 and NADA version 1.6-1 package (Therneau 2019). This statistical analysis allows working with data that are below the quantification limit, giving greater robustness to the results obtained; instead of truncating or replacing the results below of the quantification limit, either by zero or a division of the limit, causing biased results and raising the probability of making errors at the conclusions and decision-making. For pesticides with detection frequencies less than $20 \%$, according to the theory of censored data analysis, their analysis with statistical tests is not possible, and only the range, mean, and quantification frequency were reported (Hewett and Ganser 2007; Helsel 2012; Fox 2015).

For the pesticides with a detection frequency of $100 \%$ a parametric statistical analysis ANOVA, and nonparametric Kruskal-Walis tests were performed to evaluate significant differences in the concentration of the pesticides by season and sampling. The significantly non-normal data $(p<0.05)$ were normalized with the lognormal distribution. The pesticide concentrations that did not present a normal distribution were transformed with a natural logarithm or analyzed through a non-parametric test.

Statistical analysis as ANOVA, Kruskal-Wallis, and left-censored data with the non-parametric KaplanMeier (K-M) test and parametric with Maximum Likelihood Estimation (CENMLE; function "cenmle" from "NADA" package) was carried out, to determine if the spatial variables (location in the basin, geoform type, and stream order) referring to the main sources of contamination and the physical conditions of the sampling sections influence the pesticides concentrations. In analyzes censored data, the percentage of detection of pesticide concentrations determines which type of statistical test presents the best fit for data analysis. In this sense, it is recommended that pesticides with detection percentages $<50 \%$ are analyzed through the non-parametric K-M test, while pesticides with a percentage $>50 \%$ are analyzed with the parametric MLE test (Hewett and Ganser 2007; Helsel 2012).

\section{Results}

\subsection{Occurrence and concentration pesticides in otter's feces}


Eleven pesticides were quantified in the feces samples, of which one is classified as a fungicide, five herbicides, and five insecticides. Imazalil fungicide was the analyte detected at the highest concentrations during the wet season in November 2019, concentrations of 3,544.5, 1,515.9, and 1,474.3 $\mu \mathrm{kg}^{-1}$ were found at S10, S5, and S6, respectively. In addition, the imazalil concentration of 1,343.5 $\mu \mathrm{g}$ $\mathrm{kg}^{-1}$ was also detected during the dry season in February 2019 in S5. The second analyte at the highest concentration is the picloram herbicide with $1,280.7 \mathrm{\mu g} \mathrm{kg}^{-1}$ in the S10 in February 2018, corresponding to the dry season. And the third analyte at the highest concentration is the malathion insecticide with 824.4 $\mu \mathrm{g} \mathrm{kg}^{-1}$ in the S8 sample of November 2019. The pesticides atrazine, carbendazim, carbofuran, 2,4-D, dimethoate, metoxuron, parathion, pyraclostrobin, and thiabendazole were found below the quantification limit $\left(10 \mu \mathrm{gg}^{-1}\right)$ on all samples (Table 2$)$.

Table 2. Maximum concentration, average concentration, and standard deviation of all pesticides quantified in the neotropical otter's feces samplings during 2018 and 2019 of Ayuquila-Armería basin.

\begin{tabular}{|llll|}
\hline Analyte & $\begin{array}{l}\text { Maximum concentration } \\
\left(\mu \mathrm{gg}^{-1}\right)\end{array}$ & $\begin{array}{l}\text { Average } \\
\left(\mu \mathrm{kg}^{-1}\right)\end{array}$ & Standard deviation \\
\hline Acetochlor & 21.4 & - & - \\
\hline Ametrine & 216.2 & 121.2 & 90.0 \\
\hline Diazinon & 100.1 & - & - \\
\hline Emamectin & 56.4 & 55.8 & 0.3 \\
\hline Glyphosate & 373.2 & 161.0 & 81.0 \\
\hline Imazalil & 3544.5 & 457.7 & 715.3 \\
\hline$\lambda$-cyhalothrin & 75.4 & 35.7 & 15.3 \\
\hline Malathion & 824.4 & 174.9 & 194.2 \\
\hline Methomyl & 31.6 & 30.6 & 0.3 \\
\hline Molinate & 64.1 & 24.7 & 18.9 \\
\hline Picloram & 1280.7 & 340.5 & 208.8 \\
\hline
\end{tabular}

- = There are no data because the quantification of that pesticide was determined in one sample. Therefore, the highest concentration represents the only concentration quantified in that section.

Picloram, emamectin, $\lambda$-cyhalothrin, and methomyl were detected in all analyzed samples in this study (40 samples). Followed by imazalil with a detection frequency of 30 (75\%), malathion $27(67.5 \%)$, molinate 11 (27.5\%), glyphosate 10 (25\%), ametrine 3 (7.5\%) and acetochlor and diazinon both, with 1 $(2.5 \%)$. 
Samples of S7 and S8 sections presented the highest number of pesticides detected per sample during both samplings of November 2019. On the other hand, samples of the S3 section presented the least number of pesticides per sample with four, during the sampling of February 2019. In this sense, pesticides were present in all samples having at least four pesticides per sample.

\subsection{Spatiotemporal distribution of pesticides in the basin}

The number of the total pesticides detected per neotropical otter subpopulation did not show significant differences by season $\left(\right.$ Chisq $\left._{1}=0.42, n=40, P=0.51\right)$ and sampling date $\left(F_{1,38}=1.387, n=40, P=0.25\right)$. The number seems to remain relatively stable within a range of 4-8 pesticides for the group of compounds analyzed. Emamectin, $\lambda$-cyhalothrin, methomyl, and picloram were detected during the four sampling periods in all otter subpopulations. The imazalil and malathion pesticides also showed high detection rates during both seasons. During the dry season, imazalil had a detection frequency of 16 $(80 \%)$ and malathion $14(70 \%)$ in samples. While in the wet season the detection frequency was $14(70 \%)$ for imazalil and $13(65 \%)$ for malathion (Table 3$)$.

Only the emamectin distribution was normal. Therefore, a logarithmic transformation was carried out to normalize the concentrations of $\lambda$-cyhalothrin and picloram. The methomyl concentration data were analyzed by Kruskal-Walis tests. Statistical analyzes were performed with censored data for concentrations of glyphosate, imazalil, malathion, and molinate.

Table 3. Concentration range, mean concentration, and detection percentage (\%) of pesticides in otter feces of Ayuquila-Armería river in dry season samplings (February 2018 and 2019) and wet season sampling (November 2018 and 2019). 


\begin{tabular}{|lllllll|}
\hline Pesticide & Dry season & \multicolumn{5}{l|}{ Wet season } \\
\cline { 2 - 6 } & $\begin{array}{l}\text { Concentration } \\
\text { range }\left(\mu \mathrm{kg}^{-1}\right)\end{array}$ & $\begin{array}{l}\text { Mean } \\
\text { concentration } \\
\left(\mu \mathrm{kg}^{-1}\right)\end{array}$ & $\begin{array}{l}\text { D.P. } \\
(\%)\end{array}$ & $\begin{array}{l}\text { Concentration } \\
\text { range }\left(\mu \mathrm{kg}^{-1}\right)\end{array}$ & $\begin{array}{l}\text { Mean } \\
\text { concentration } \\
\left(\mu \mathrm{kg}^{-1}\right)\end{array}$ & $\begin{array}{l}\text { D.P. } \\
(\%)\end{array}$ \\
\hline Acetochlor & No pesticide detection & & $<$ LD-21.4 & - & 5 \\
\hline Ametrine & $<$ LD-110.1 & - & 5 & $<$ LD-216.2 & 126.8 & 10 \\
\hline Diazinon & No pesticide detection & & $<$ LD-100.1 & - & 5 \\
\hline Emamectin & $55.3-56.0$ & 55.7 & 100 & $55.4-56.4$ & 55.9 & 100 \\
\hline Glyphosate & $<$ LD-187.4 & 160.8 & 15 & $<$ LD-373.2 & 161.1 & 35 \\
\hline Imazalil & $<$ LD-1,343.5 & 268.7 & 80 & $<$ LD-3,544.5 & 673.7 & 70 \\
\hline$\lambda$ - & $16.2-74.1$ & 35.4 & 100 & $17.3-75.4$ & 35.9 & 100 \\
\hline Cyhalothrin & & & 70 & $<$ LD-824.4 & 231.0 & 65 \\
\hline Malathion & $<$ LD-457.4 & 137.8 & 100 & $30.4-31-6$ & 30.6 & 100 \\
\hline Methomyl & $30.4-31.2$ & 30.5 & 25 & $<$ LD-34.5 & 17.4 & 30 \\
\hline Molinate & $<$ LD-64.1 & 33.4 & 100 & $139.4-766.8$ & 324.2 & 100 \\
\hline Picloram & $170-1280.7$ & 356.9 & & & & \\
\hline
\end{tabular}

D.P. = detection percentage in all samples. - = There are no data because the quantification of that pesticide was determined in one sample. Therefore, the highest concentration in the range represents the only concentration quantified in that season. $<$ LD $=$ below of the quantification limit $(10 \mu \mathrm{g} \mathrm{kg-1)}$.

The number of pesticides detected from the otter subpopulations was higher during the wet season, except for molinate and picloram. Statistical test results indicate that ememactin is the only pesticide with statistical differences $\left(F_{1,38}=5.328, n=40, P=0.001\right)$ between seasons (Table 4). Also, the emamectin $\left(F_{1,38}=5.328, n=40, P=0.02\right)$ pesticide also exhibited significant differences by sampling date. Figure 2 shows the temporal distribution of emamectin concentrations.

Table 4. Results of the statistical test of pesticide concentrations in otter's feces by season and sampling date in the Ayuquila-Armería river. 


\begin{tabular}{|llll|}
\hline Analyte & Statistical test & $\begin{array}{l}\text { Season } \\
(p \text {-value })\end{array}$ & $\begin{array}{l}\text { Sampling date } \\
(p \text {-value })\end{array}$ \\
\hline Emamectin & ANOVA & $<0.01^{*}$ & $0.01^{*}$ \\
\hline Glyphosate & Maximum likelihood estimation & 0.14 & 0.26 \\
\hline Imazalil & Kaplan-Meier & 0.90 & 0.05 \\
\hline$\lambda$-cyhalothrin & ANOVA & 0.84 & 0.13 \\
\hline Malathion & Kaplan-Meier & 0.90 & 0.30 \\
\hline Methomyl & Kruskal-Wallis & 0.31 & 0.76 \\
\hline Molinate & Maximum likelihood estimation & 0.89 & 0.96 \\
\hline Picloram & ANOVA & 0.84 & 0.78 \\
\hline
\end{tabular}

*=Statistically significant

The statistical analysis results of censored data with all results of pesticides detected per subpopulation of otter without distinguishing by season or sampling date showed significant differences with the concentration of molinate and malathion. The molinate concentration showed difference by location in basin $\left(\right.$ Chisq $\left._{1}=4.31, n=40, P=0.038\right)$. In the case of the variable "location in the basin", the middle part of the basin had a lower molinate detection frequency than the lower part, whereas the concentrations were higher in the lower part than in the middle part of the basin. The statistical analysis results for the other pesticides did not show significant differences with any spatial variable used in this study. Figure 3 shows the spatial distribution of molinate concentrations.

\section{Discussion}

Otter feces have been widely used worldwide to assess the degree of contamination or exposition of their populations (Lemarchand et al. 2007). The use of feces should be considered as a first approach to determine the pesticide exposure status of otter populations. However, not all the pesticide concentrations detected in the feces represent the accumulated concentration within the organism; since the excretion mechanism is only one of the physiological processes of contaminants elimination and the concentration of pesticides depends on the physicochemical characteristics of each active ingredient (Mason et al. 1992; Elliot et al. 2008).

The neotropical otter subpopulations under study were mostly found in sections influenced by either domestic, industrial, livestock, or agricultural residual discharges (Díaz-Gallardo et al. 2005). In the sampling sections located immediately downstream of the Autlán-El Grullo valley where most of the aforementioned discharges converge, otter subpopulations density is high (Díaz-Gallardo et al. 2005; Brito-Ríos 2017); this situation matches with Delibes et al. (2009) and Monroy-Vilchis and Mundo (2009) studies that evidenced that otters present tolerance to stress conditions such as habitat alteration, 
including chemical and organic contamination; however, this is contrary to what Lavière (1999) proposed. According to our results on pesticide concentrations, the neotropical otter species could not be considered as sensitive to agrochemical contamination as several authors have pointed out (Lodé 1993; CasariegoMadorell et al. 2006). From the published works of Kruuk and Conroy (1996) and Guerrero-Flores et al. (2013) can be concluded that the species presents a tolerance towards disturbing factors, such as pollutant discharges and deforestation of riparian vegetation, with the availability of food being a more important factor. However, otter subpopulations could remain threatened by toxic effects in the medium and long term (Lemarchand et al. 2007), which deserves further research.

In all the feces of the different subpopulations of otter understudy emamectin, $\lambda$-cyhalothrin, methomyl, and picloram were present, which indicates their current usage in agriculture for the control of grasses and insects. Furthermore, the subpopulations of otters presented an average of six pesticides during sampled periods (Rodríguez-Aguilar et al. 2019). In addition, results coincide with those obtained by Lemarchand et al. (2010), as $100 \%$ of the samples had pesticides concentrations so that none of the subpopulations were completely free of toxic contaminants. Likewise, the 11 pesticides detected in all samples from the Ayuquila-Armería basin coincide with the results obtained by Carpenter et al. (2014).

The results indicate that the sampling sections do not present significant differences based on the number of pesticides detected per sample, therefore the number of pesticides remains similar regardless of the location of the sampling section, this situation does not coincide with that stated by Mason and McDonald (1993) and Lemarchand et al. (2007). This is due to otters incorporate a wide variety of preys in their diet, which can vary according to their opportunistic nature and due to spatial and temporal issues (Rangel-Aguilar and Gallo-Reynoso 2013). The pesticides detected in the feces of the otter subpopulations do not show temporal differences except for the emamectin. This allows us to deduce that the neotropical otter of the Ayuquila-Armería basin is continuously collecting these pesticides regardless of the time of year. Although emamectin presented a significant variation according to the season, from the toxicological point of view, its slight variation in the concentrations in the dry and wet seasons would not generate significantly different effects (EFSA 2012).

There are no temporal differences in most of the analytes, which can indicate that pesticides in the Ayuquila-Armería basin show a "pseudo-persistent" behavior, as is suggested by Daughton (2003) and Primost et al. (2017). This behavior could be due to the intensive use of pesticides in the basin, which means that the otters have not finished degradation or transformation of the acquired pesticides when they ingest new quantities of them. This situation of "stability" in pesticide concentrations in otters is distressing, particularly in the dry season, since this period of the year is when occurs the highest number of births, and therefore the highest risk of maternal transfer, as was stated by Lemarchand et al. (2007) and Ramos-Rosas et al. (2012).

Elliot et al. (2008) determined $0.28 \mathrm{mg} \mathrm{kg}^{-1}$ as a total mean concentration of organochlorine pesticides in the feces of river otters (Lontra canadensis) in Canada was $0.28 \mathrm{mg} \mathrm{kg}^{-1}$. Mason and McDonald (1993) analyzed concentrations of organochlorine compounds in feces from Lutra lutra in western Great Britain, 
obtaining mean concentrations of $0.46,1.69$, and $2.74 \mathrm{mg} \mathrm{kg}^{-1}$ for lindane, dieldrin, and DDT, respectively. Likewise, Mason and Mcdonald (1994) also analyzed concentrations of organochlorine compounds in feces of $L$. lutra in England, detecting means concentrations of $0.98 \mathrm{mg} \mathrm{kg}^{-1}$ of dieldrin and $1.5 \mathrm{mg} \mathrm{kg}^{-1}$ of p, p-DDE. Furthermore, Latorre-Cárdenas (2013) analyzed the concentrations of organochlorine pesticides in feces of $L$. longicaudis in Mexico and detected average concentrations of $0.37,0.61,6.74$, 0.97 , and $0.08 \mathrm{mg} \mathrm{kg}^{-1}$ for chlordane, DDTs, drines, endosulphanes, and heptachlor. Although the pesticide concentrations in the otter subpopulations of the Ayuquila-Armería basin were relatively low compared to other similar studies and were below the acute and chronic effect limits, they are widely dispersed in the studied basin (AERU 2020).

Chlorinated pesticides are easily accumulated in the body since they present octanol-water partition coefficients (Kow) generally ranging from moderate to high-fat solubility; presenting an excretion rate of approximately $10 \%$ of the total acquired compound, which is relatively low and its presence in environmental matrices is the product of its historical application and residuality (Mason et al. 1992; Mason and Mcdonald 1993; AERU 2020). Pesticide concentrations detected in this study, unlike the chlorinated ones, are commonly used products in the current agricultural production system within the basin and are considered not so residual compared to organochlorines. In this sense, they are more easily solubilized and subsequently excreted. However, this does not mean that these compounds are not involved in accumulative processes (Martínez-Valenzuela and Gómez-Arroyo 2007; Mamta et al. 2019). In this sense, the bioaccumulation and biomagnification of pesticides allow reaching critical concentrations levels that can be a factor that adversely affects otter populations causing their decrease (Mason and Mcdonald 1994; Mason and Ratford 1994). Therefore, due to the trophic level of the neotropical otter in the Ayuquila-Armería river and the wide diversity in its diet, there is a possibility that they accumulate high concentrations of pesticides in their tissues (Kannan et al. 2000; Rangel-Aguilar and Gallo-Reynoso 2013).

In this sense, lower concentrations compared to similar studies are reported, which does not mean that otter populations are out of danger. The presence of blended pesticides represents a potential risk for the otter populations in the Ayuquila-Armería basin, as stated by Elliott et al. (2008), Latorre-Cárdenas (2013), and Carpenter et al. (2014). Blended pesticides give the possibility of synergistic, cumulative, and antagonistic adverse effects in the $L$. longicaudis populations. The synergistic effects of a pesticide mixture are the most unknown among the three types, nevertheless, some studies have shown that the probability of presenting these effects increases according to the number of contaminants detected. In this sense, those adverse effects are not only caused by pesticides but also by pharmaceutical and veterinary products, which are simultaneously poured into the environment and thus, increases the probability that an exposed organism will present those effects (Kim et al. 2005; Baek et al. 2019). The neotropical otter should be viewed as a sentinel species due to its ability to accumulate pollutants and its dietary similarity with humans (Van der Schalie et al. 1999). Most communities adjacent to the AyuquilaArmería river, take advantage of the fishing resources for commercial or subsistence purposes (MercadoSilva et al. 2011). 
The molinate increased its concentration from the middle to the lower part of the basin, and unlike Lemarchand et al. (2007) intensive agricultural activity in the basin is carried out in both the middle and lower parts of the basin. Therefore, the concentration increase in the lower part could be because of either a dietary variation or the cumulative effect on the transport of this pesticide through the river, due to its high solubility in water (EC 2003).

There are limitations to using feces for concentration analysis of pesticides in otter populations. A relevant one is that it is not known with certainty if the feces represent the current situation of contamination in the population, as there is a fraction of the pollutants that are absorbed and another that is excreted. Also, the complexity in differencing the feces from male and female; and the differentiation of otters ages that excrete the sample (Shore et al. 2000) affect the uncertainty of the analysis. However, as the neotropical otter is a protected species in México (SEMARNAT 2010), the generation of information becomes a priority, to generate management actions for its conservation. Therefore, the use of feces, accepted as a non-invasive method to evaluate the degree of exposure to pesticides, should be applied to determine sites with pollution problems affecting the neotropical otter (Mason et al. 1992; Elliot et al. 2008).

\section{Conclusion}

In this work, and based on these results, the distribution of L. longicaudis populations in the AyuquilaArmería basin does not respond to the degree of contamination by pesticides in surface water or to the proximity to agricultural activities, and that in sites with evident chemical and organic contamination and human presence, as sampling section $\mathrm{S} 3$, a significant amount of excreta was obtained, in addition to the fact that it has been reported that there are sites with high densities in the basin (Díaz-Gallardo et al. 2005; Brito-Ríos 2017; Rodríguez-Aguilar et al. 2019). Therefore, factors such as the availability and size of the food and the physicochemical conditions of the surface water could be more influential in the otters' distribution within the basin (Kruuk and Conroy 1996). However, the wide distribution of the neotropical otter in the basin even in sections with pesticide contamination does not mean that they are healthy since these compounds generally induce chronic effects that are reflected in the medium and long term (Thorson et al. 2020).

\section{Declarations}

Funding: This research received no specific grant from any funding agency

Conflicts of interest/Competing interests: The authors declare that they have no conflict of interest.

Availability of data and material: All data generated and analyzed during this study are included in this published article

Code availability: No code available 


\section{References}

1. AERU (Agriculture \& Environment Research Unit) (2020) Pesticide Properties DataBase of University of Hertfordshire A review. https://sitem.herts.ac.uk/aeru/ppdb/en/index.htm. Accessed 04 April 2021

2. Albert LA (2005) Panorama de los plaguicidas en México. Revista de Toxicología en Línea 8:1-17

3. Aranda-Sánchez JM (2012) Manual para el rastreo de mamíferos silvestres de México. Comisión Nacional para el Conocimiento y Uso de la Biodiversidad, México

4. Arias-Estévez M, López-Periago E, Martínez-Carballo E, Simal-Gándara J, Mejuto JC, García-Río L (2008) The mobility and degradation of pesticides in soils and the pollution of groundwater resources. Agr Ecosyst Environ 123:247-260. https://doi.org/10.1016/j.agee.2007.07.011

5. Baek IH, Kim Y, Baik S, Kim J (2019) Investigation of the synergistic toxicity of binary mixtures of pesticides and pharmaceuticals on AliiVibrio fischeri in Major River Basins in South Korea. Int J Env Res Public Health 16:208. https://doi.org/10.3390/ijerph16020208

6. Bejarano-González F (2017) Los plaguicidas altamente peligrosos en México. Red de Acción sobre Plaguicidas y Alternativas en México, A.C. México

7. Benítez-Díaz P, Miranda-Contreras L (2013) Contaminación de aguas superficiales por residuos de plaguicidas en Venezuela y otros países de latinoamerica. Rev Int Contam Ambie 29:7-23

8. Brito-Ríos JGA (2017) Estado de conservación de la nutria neotropical (Lontra longicaudis) en cuencas de la Reserva de la Biosfera Sierra de Manantlán. Dissertation, University of Guadalajara

9. Carpenter S, Mateus-Pinilla NE, Singh K, Lehner A, Satterthwaite-Phillips D, Bluett RD, Rivera NA, Novakofski JE (2014) River otters as biomonitors for organochlorine pesticides, PCBs, and PBDEs in Illinois. Ecotox Environ Safe 100:99-104. https://doi.org/10.1016/j.ecoenv.2013.07.028

10. Casariego-Madorell MA, List R, Ceballos G (2006) Aspectos básicos sobre la ecología de la nutria de río (Lontra longicaudis annectens) para la costa de Oaxaca. Revista Mexicana de Mastozoología 10:71-74. https://doi.org/10.22201/ie.20074484e.2006.10.1.143

11. CITES (Convention on International Trade in Endangered Species of Wild Fauna and Flora) (2009) UNEP-WCMC Species database: CITES-listed species. http://checklist.cites.org/\#/es. Accessed 12 May 2021

12. Daughton CG (2003) Cradle-to-Cradle Stewardship of Drugs for Minimizing Their Environmental Disposition While Promoting Human Health. I. Rationale for and Avenues toward a Green Pharmacy. Environ Health Persp 111:757-774. https://doi.org/10.1289/ehp.5947

13. Delibes M, Cabezas S, Jiménez B, González MJ (2009) Animal decisions and conservation: the recolonization of a severely polluted river by the Eurasian otter. Anim conserv 12:400-407. https://doi.org/10.1111/j.1469-1795.2009.00263.x

14. Díaz-Gallardo N, Iñiguez-Dávalos LI, Santana-Castellón E (2005) Ecología y conservación de la nutria (Lontra longicaudis) en la cuenca baja del río Ayuquila, Jalisco. In: Sánchez-Rojas G, Rojas-Martínez A (eds) Tópicos en sistemática, biogeografía, ecología y conservación de mamíferos, 1st edn. Universidad Autónoma del Estado de Hidalgo, México, pp 165-182 
15. EC (European Commission) (2003) Review report for the active substance molinate SANCO/3047/99. https://ec.europa.eu/food/plant/pesticides/eu-pesticides-database/public/? event=activesubstance. detail\&language=EN\&selectedID=1598. Accessed 13 June 2021

16. EFSA (European Food Safety Authority) (2012) Conclusion on the peer review of the pesticide risk assessment of the active substance emamectin. https://efsa.onlinelibrary.wiley.com/doi/epdf/10.2903/j.efsa.2012.2955. Accessed 13 June 2021

17. Elliott JE, Guertin DA, Balke JME (2008) Chlorinated hydrocarbon contaminants in feces of river otters from the southern Pacific coast of Canada, 1999-2004. Sci Total Environ 397:58-71. https://doi.org/10.1016/j.scitotenv.2008.01.063

18. Fox GA (2015) What you don't know can hurt you: censored and truncated data in ecological research. In: Fox GA, Negrete-Yankelevich S, Sosa VJ (eds) Ecological Statistics: Contemporary Theory and Application, 1st edn. Oxford University Press, New York, pp 106-130

19. Gallo-Reynoso JP (1989) Distribución y estado actual de la nutria o perro de agua (Lutra longicaudis annectens Major, 1897) en la Sierra Madre del Sur, México. Revista Mexicana de Mastozoología 2:10-32

20. Gallo-Reynoso JP (1997) Situación y distribución de las nutrias en México, con énfasis en Lontra longicaudis annectens Major, 1897. Dissertation, National Autonomous University of Mexico

21. Gallo-Reynoso JP, Casariego MA (2005) Nutria de río, perro de agua. In: Ceballos G, Oliva G (eds) Los mamíferos silvestres de México, 1st edn. Comisión Nacional para el Conocimiento y uso de la Biodiversidad Fondo de Cultura Económica México, Mexico, pp 374-376

22. Gallo-Reynoso JP, Ramos-Rosas NN, Rangel-Aguilar O (2008) Depredación de aves acuáticas por la nutria neotropical (Lontra longicaudis annectens), en el río Yaqui. Sonora México Revista mexicana de biodiversidad 79:275-279. https://doi.org/10.22201/ib.20078706e.2008.001.502

23. Guerrero-Flores JJ, Macías-Sánchez S, Mundo-Hernández V, Méndez-Sánchez F (2013) Ecología de la nutria (Lontra longicaudis) en el municipio de Temascaltepec, Estado de México: estudio de caso. Therya 4:231-242. https://doi.org/10.12933/therya-13-127

24. Gutleb AC, Kranz A (1997) Estimation of polychlorinated biphenyl (PCB) levels in livers of the otter (Lutra lutra) from concentrations in scats and fish. Water Air Soil Pollut 106:481-491. https://doi.org/10.1007/978-1-4612-0625-5_4

25. Helsel DR (2012) Statistics for censored environmental data using Minitab® and R. John Wiley \& Sons, Inc. New Jersey, USA

26. Hewett P, Ganser GH (2007) A comparison of several methods for analyzing censored data. Ann Occup Hyg 51:611-632. https://doi.org/10.1093/annhyg/mem045

27. Kannan K, Blankenship AL, Jones PD, Giesy JP (2000) Toxicity Reference Values for the Toxic Effects of Polychlorinated Biphenyls to Aquatic Mammals. Hum Ecol Risk Assess 6:181-201. https://doi.org/10.1080/10807030091124491

28. Kim J, Kim S, Schaumann GE (2013) Reliable predictive computational toxicology methods for mixture toxicity: Toward the development of innovative integrated models for environmental risk 
assessment. Rev Environ Sci Biotechnol 12:235-256. https://doi.org/10.1007/s11157-012-9286-7

29. Kruuk H, Conroy JWH (1996) Concentrations of some organochlorines in otters (Lutra lutra L.) in Scotland: implications for populations. Environ Pollut 92:165-171. https://doi.org/10.1016/02697491(95)00099-2

30. Kruuk H, Conroy JWH, Webb A (1997) Concentrations of mercury in otters (Lutra lutra L.) in Scotland in relation to rainfall. Environ Pollut 96:13-18. https://doi.org/10.1016/S0269-7491(97)00011-0

31. Larivière S (1999) Lontra longicaudis. Mamm Species 65:9-13

32. Latorre-Cárdenas MC (2013) Evaluación del estrés fisiológico, la bioacumulación de contaminantes orgánicos persistentes y la calidad del hábitat de la nutria neotropical (Lontra longicaudis) en Veracruz, México. Dissertation, Instituto de Ecología, A.C, México

33. LeDoux M (2011) Analytical methods applied to the determination of pesticide residues in foods of animal origin. A review of the past two decades. J Chromatogr A 1218:1021-1036. https://doi.org/10.1016/j.chroma.2010.12.097

34. Lemarchand C, Amblard C, Souchon Y, Berny P (2007) Organochlorine Compounds (pesticides and PCBs) in Scats of the European Otter (Lutra lutra) from an Actual Expanding Population in Central France. Water Air Soil Pollut 186:55-62. https://doi.org/10.1007/s11270-007-9462-5

35. Lemarchand C, Rosoux R, Berny P (2010) Organochlorine pesticides, PCBs, heavy metals and anticoagulant rodenticides in tissues of Eurasian otters (Lutra lutra) from upper Loire River catchment (France). Chemosphere 80:1120-1124. https://doi.org/10.1016/j.chemosphere.2010.06.026

36. Lemarchand C, Rosoux R, Berny P (2011) Ecotoxicology of the Eurasian otter (Lutra lutra) along Loire river (France) and predictable trends due to global change. IUCN Otter Specialist Group Bulletin 28:514

37. Lodé $T$ (1993) The decline of otter Lutra lutra populations in the region of the Pays de Loire, western France. Biol Conserv 65:9-13. https://doi.org/10.1016/0006-3207(93)90190-C

38. Lyons J, González-Hernández G, Soto-Galera E, Guzmán-Arroyo M (1998) Decline of freshwater fishes and fisheries in selected drainages of west central Mexico. Fisheries 23:10-18. https://doi.org/10.1577/1548-8446(1998)023<0010:DOFFAF>2.0.C0;2

39. Mamta RJ, Wani KA (2019) Status of Organochlorine and Organophosphorus Pesticides in Wetlands and Its Impact on Aquatic Organisms. Environ Claims J 31:1-35. https://doi.org/10.1080/10406026.2018.1519315

40. Martínez-Valenzuela C, Gómez-Arroyo S (2007) Riesgo genotóxico por exposición a plaguicidas en trabajadores agrícolas. Rev Int Contam Ambie 23:185-200

41. Mason CF, Macdonald SM (1993) Impact of organochlorine pesticide residues and PCBs on otters (Lutra lutra): a study from western Britain. Sci Total Environ 138:127-145. https://doi.org/10.1016/0048-9697(93)90410-8

42. Mason CF, Macdonald SM, Bland HC, Ratford J (1992) Organochlorine pesticide and PCB contents in otter (Lutra lutra) scats from western Scotland. Water Air Soil Pollut 64:617-626. 
https://doi.org/10.1007/BF00483370

43. Mason CF, Macdonald SM (1994) PCBs and organochlorine pesticide residues in otters (Lutra lutra) and otter spraints from SW England and their likely impact on populations. Sci Total Environ 144:305-312. https://doi.org/10.1016/0048-9697(94)90450-2

44. Mason CF, Ratford JR (1994) PCB Congeners in Tissues of European Otter (Lutra lutra). B Environ Contam Tox 53:548-554. https://doi.org/10.1007/BF00199025

45. Mercado-Silva N, Santana-Castellón E, Martínez-Rivera LM, Lyons J, Moermond T (2011) Subsistence fisheries in the Sierra Manantlán Biosphere Reserve (Jalisco/Colima, Mexico). E-Gnosis 9:1-19

46. Meza-Rodríguez D (2006) Caracterización hidrográfica de la Cuenca Ayuquila-Armería mediante la aplicación de un sistema de información geográfica. Dissertation, University of Guadalajara, Mexico

47. Monroy-Vilchis O, Mundo YV (2009) Nicho trófico de la nutria neotropical (Lontra longicaudis) en un ambiente modificado, Temascaltepec, México. Revista Mexicana de Biodiversidad 80:801-806. https://doi.org/10.22201/ib.20078706e.2009.003.175

48. Pinto MI, Burrows HD, Sontag G, Vale C, Noronha JP (2016) Priority pesticides in sediments of European coastal lagoons: A review. Mar Pollut Bull 112:6-16. https://doi.org/10.1016/j.marpolbul.2016.06.101

49. Primost JE, Marino DJG, Aparicio VC, Costa JL, Carriquiriborde P (2017) Glyphosate and AMPA, "pseudo-persistent" pollutants under real-world agricultural management practices in the Mesopotamic Pampas agroecosystem Argentina. Environ Pollut 229:771-779. https://doi.org/10.1016/j.envpol.2017.06.006

50. Ramos-Rosas NN, Valdespino C, García-Hernández J, Gallo-Reynoso JP, Olguín EJ (2012) Heavy metals in the habitats and throughout the food chain of the Neotropical otter, Lontra longicaudis, in protected Mexican wetlands. Environ Monit Assess 185:1163-1173. https://doi.org/10.1007/s10661-012-2623-z

51. Rangel-Aguilar O, Gallo-Reynoso JP (2013) Hábitos alimenticios de la nutria neotropical (Lontra longicaudis annectens) en el Río Bavispe-Yaqui, Sonora, México. Therya 4:297-309. https://doi.org/10.12933/therya-13-135

52. Rodríguez-Aguilar BA, Martínez-Rivera LM, Peregrina-Lucano AA, Ortiz-Arrona Cl, CárdenasHernández OG (2019) Analysis of pesticide residues in the surface water of the Ayuquila-Armeria river watershed, Mexico. Terra Latinoamericana 37:151-161.

https://doi.org/10.28940/terra.v37i2.462

53. Roos AM, Bäcklin BVM, Helander BO, Rigét FF, Eriksson UC (2012) Improved reproductive success in otters (Lutra lutra), grey seals (Halichoerus grypus) and sea eagles (Haliaeetus albicilla) from Sweden in relation to concentrations of organochlorine contaminants. Environ Pollut 170:268-275. https://doi.org/10.1016/j.envpol.2012.07.017

54. Santana E, Navarro S, Martínez LM, Aguirre A, Figueroa P, Aguilar C (1993) Contaminación, aprovechamiento y conservación de los recursos acuáticos del Río Ayuquila, Reserva de la Biosfera 
Sierra de Manantlán, Jalisco-Colima. Tiempos de Ciencia 30:29-38

55. SEMARNAT (Secretaría de Medio Ambiente y Recursos Naturales) (2010) Norma Oficial Mexicana, NOM-059-SEMARNAT-2010. Protección ambiental-Especies nativas de México de flora y fauna silvestres-Categorías de riesgo y especificaciones para su inclusión, exclusión o cambio-Lista de especies en riesgo.

https://www.profepa.gob.mx/innovaportal/file/435/1/NOM_059_SEMARNAT_2010.pdf. Accessed 12 de mayo de 2021

56. Shore RF, Walker LA, Wienburg CL (2000) Integrated approaches to the analysis of contaminants in otters. In: Conroy JWH, Yoxon P, Gutleb AC (eds) Proceedings of the First Otter Toxicology Conference. International Otter Survival Fund, Scotland, pp 81-92

57. Shukla G, Kumar A, Bhanti M, Joseph PE, Taneja A (2006) Organochlorine pesticide contamination of groundwater in the city of Hyderabad. Environ Int 32:244-247.

https://doi.org/10.1016/j.envint.2005.08.027

58. Sierra-Diaz E, Celis-de la Rosa AJ, Lozano-Kasten F, Trasande L, Peregrina-Lucano AA, SandovalPinto E, Gonzalez-Chavez H (2019) Urinary Pesticide Levels in Children and Adolescents Residing in Two Agricultural Communities in Mexico. Int J Env Res Public Health 16:562. https://doi.org/10.3390/ijerph16040562

59. Sumon KA, Rashid H, Peeters ET, Bosma RH, Van den Brink PJ (2018) Environmental monitoring and risk assessment of organophosphate pesticides in aquatic ecosystems of north-west Bangladesh. Chemosphere 206:92-100. https://doi.org/10.1016/j.chemosphere.2018.04.167

60. Therneau TM (2019) Survival analysis. https://github.com/therneau/survival. Accessed 9 March 2020

61. Thorson JLM, Beck D, Maamar MB, Nilsson EE, Skinner MK (2020) Epigenome-wide association study for pesticide (Permethrin and DEET) induced DNA methylation epimutation biomarkers for specific transgenerational disease. Environ Health 19:109. https://doi.org/10.1186/s12940-02000666-y

62. Rheingantz ML, Trinca CS (2015) Lontra longicaudis. http://iucnredlist.org. Accessed 12 May 2021

63. Van der Schalie WH, Gardner HS, Bantle JA, De Rosa CT, Finch RA, Reif JS, Reuter RH, Backer LC, Burger J, Folmar LC, Stokes WS (1999) Animals as Sentinels of Human Health Hazards of Environmental Chemicals. Environ Health Perspect 107:309-315. https://doi.org/10.1289/ehp.99107309

64. Zhou Q, Zhang J, Fu J, Shi J, Jiang G (2008) Biomonitoring: An appealing tool for assessment of metal pollution in the aquatic ecosystem. Anal Chim Acta 606:135-150. https://doi.org/10.1016/j.aca.2007.11.018

\section{Figures}




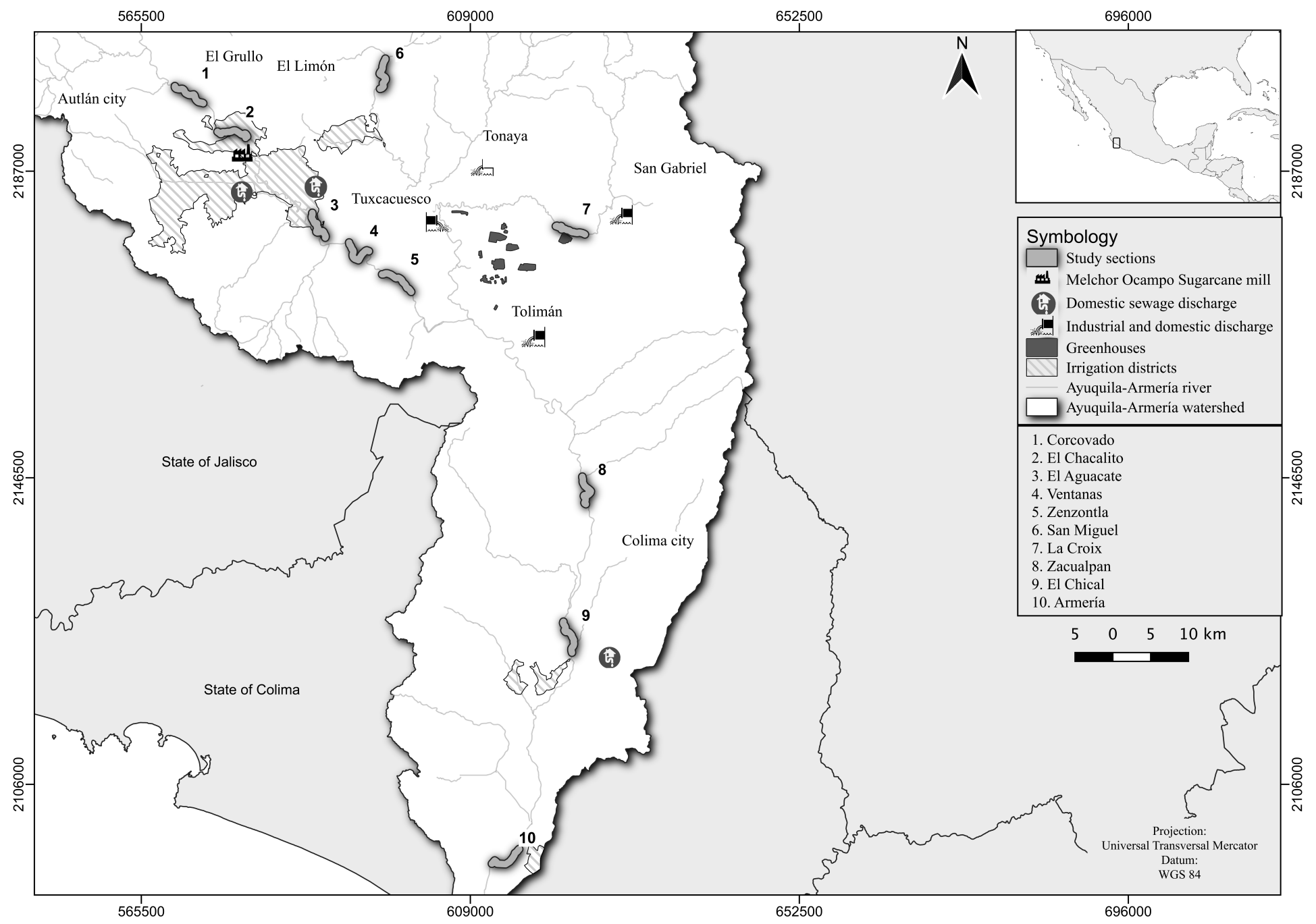

Figure 1

Sampling sections and main sources of contamination in the Ayuquila-Armería basin in western Mexico 
a

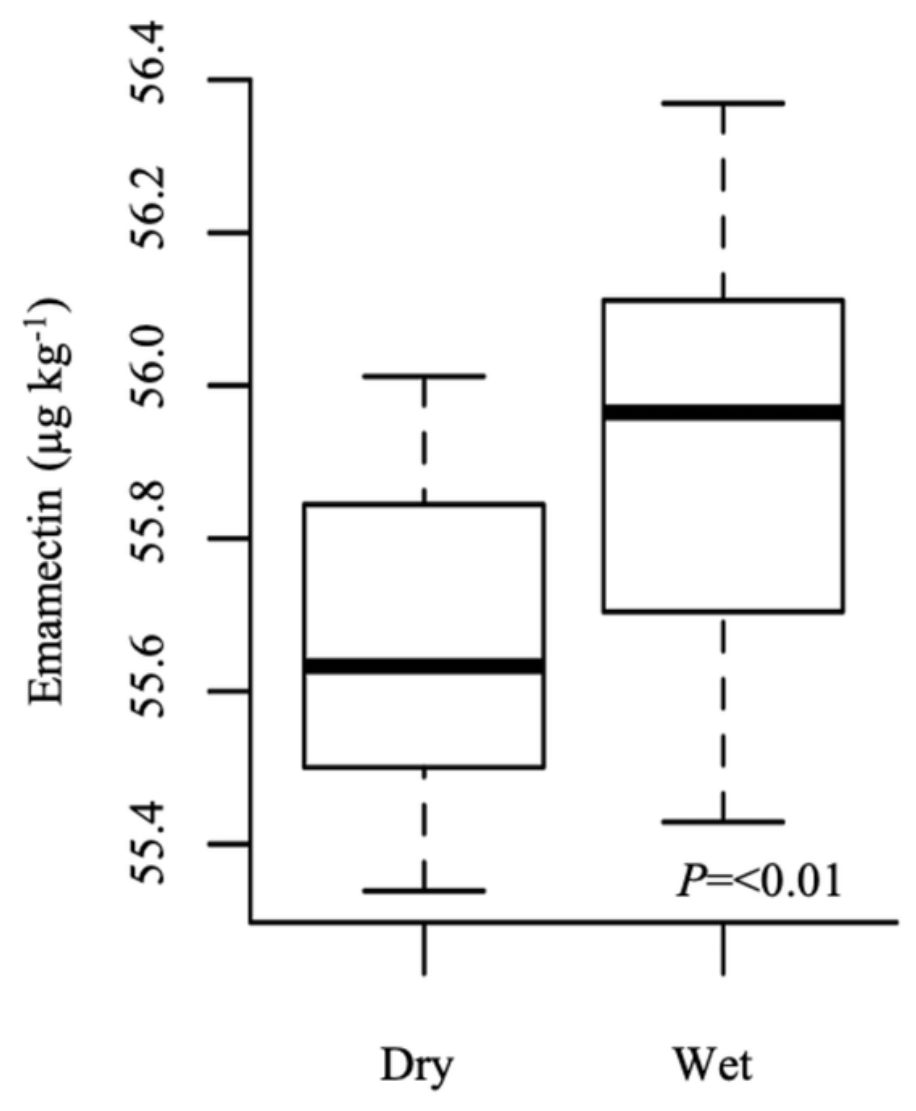

b

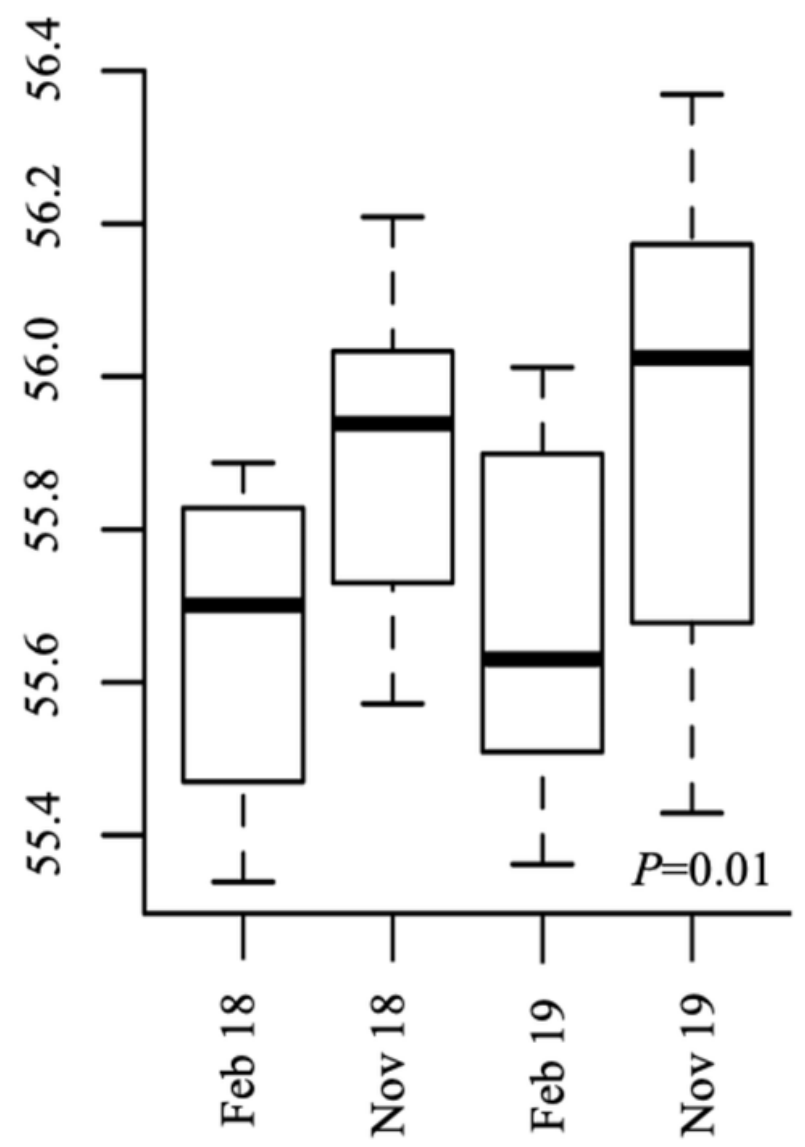

Figure 2

Temporal distribution of emamectin concentrations, A) Boxplot emamectin concentration by season, B) Boxplot emamectin concentration by field sampling date. The black line inside the box represents the median $25 \%$ and $50 \%$ percentiles (box), maximum and minimum (whiskers) 
a

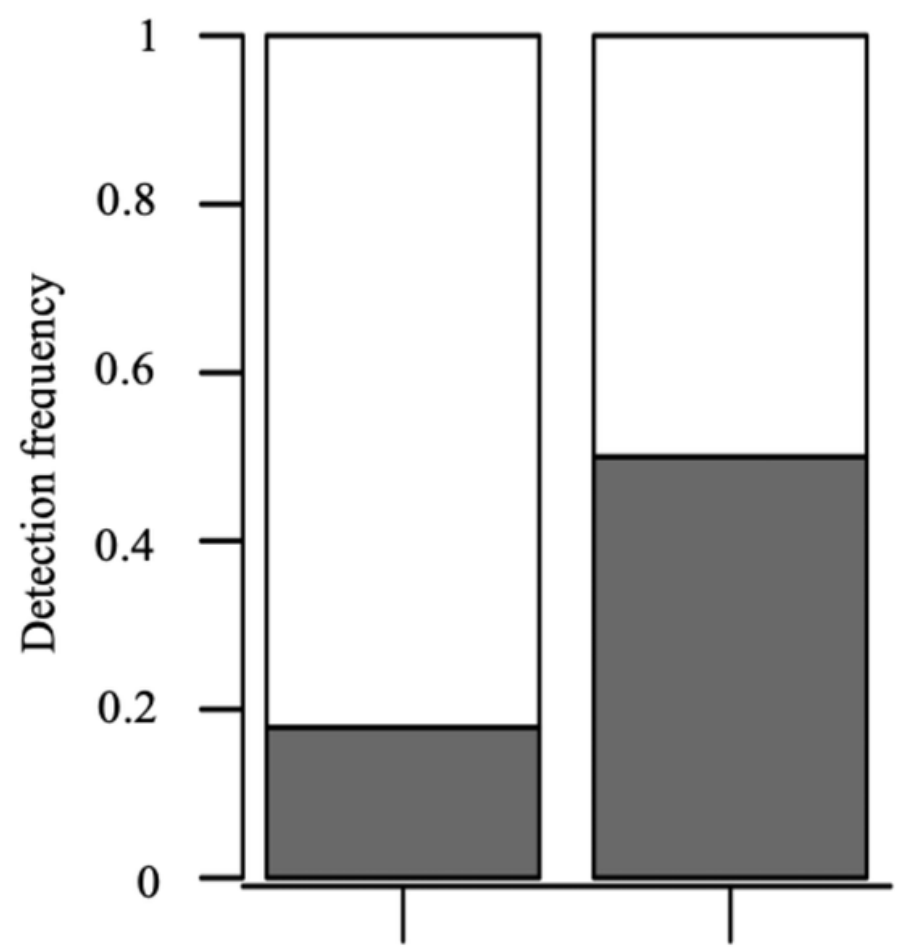

Middle
Lower b

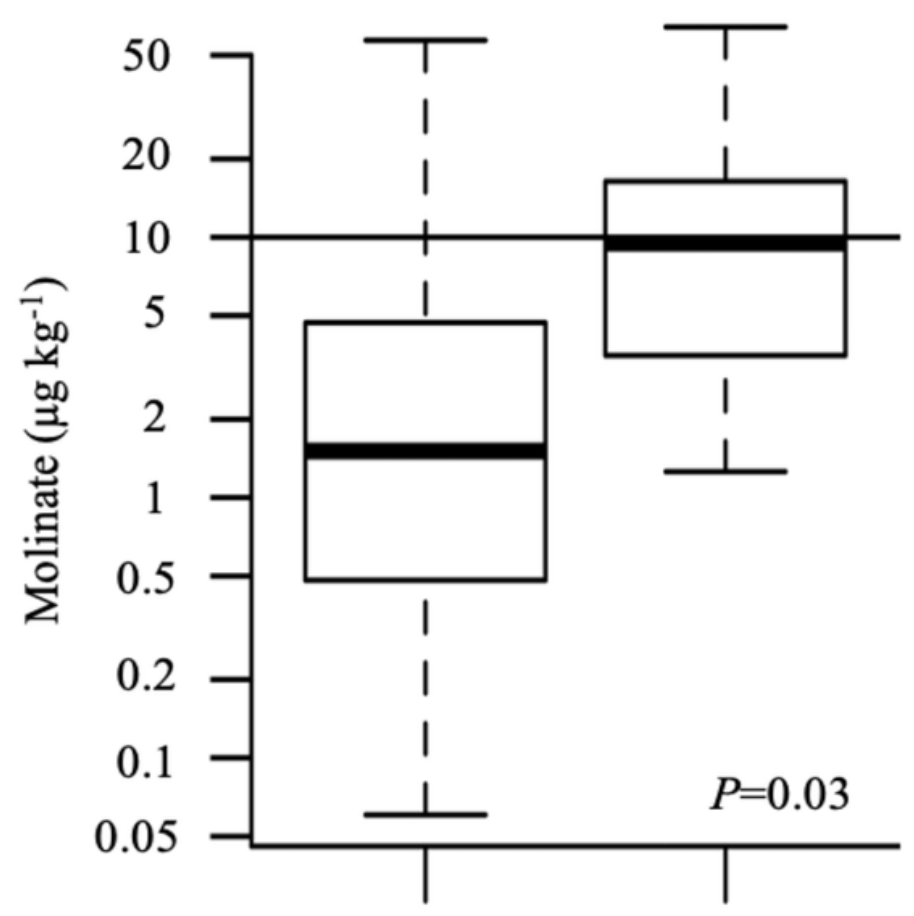

Middle

\section{Lower}

\section{Figure 3}

Spatial distribution of molinate concentrations, A) Barplot emamectin detection frequency by location in a basin, B) Boxplot molinate concentration by location in the basin. Detected concentration (white dots), the horizontal line represents the quantification limit $(10 \mu \mathrm{g} \mathrm{kg}-1)$, black line inside the box represents the median $25 \%$ and $50 \%$ percentiles (box), maximum and minimum (whiskers). The estimate of central tendency metrics was calculated with maximum likelihood estimation ("MLE") for censored data (Helsel, 2012) 